\title{
Changes in body mass during weight loss treatment - a two-year prospective study
}

\author{
Zmiany masy ciała w trakcie terapii odchudzającej - dwuletnie badanie \\ prospektywne
}

\author{
Katarzyna Krekora-Wollny, Edyta Suliga \\ Department of Prevention of Alimentary Tract Diseases, Faculty of Medicine and Health Science, Jan Kochanowski University, Kielce, \\ Poland \\ Head of the Department: Prof. Grażyna Rydzewska MD, PhD
}

Medical Studies/Studia Medyczne 2017; 33 (4): 290-294

DOI: https://doi.org/10.5114/ms.2017.72482

Key words: body mass index, body composition, weight loss, weight maintenance.

Słowa kluczowe: wskaźnik masy ciała, skład ciała, utrata masy ciała, utrzymanie masy ciała.

\begin{abstract}
Introduction: A reduction of 5\% to $10 \%$ of body mass is related to a significantly lower risk of the occurrence of conditions whose underlying cause is obesity.

Aim of the research: The analysis of body mass and body composition changes in overweight and obese patients undergoing weight loss treatment.

Material and methods: A total of 129 overweight and obese individuals qualified for the study. All patients were instructed to follow a healthy, balanced diet based on the nutritional standards. The patients were subjected to anthropometric measurements and body composition tests by means of bioimpedance analysis. The analysis included measurements performed $3,6,12$, and 24 months after the first appointment. One-factor analysis of variance was applied to test the changes of body mass and composition in the following months.

Results: The average body mass index of the patients decreased on consequent follow-up appointments from $33.8 \pm 5.17 \mathrm{~kg} / \mathrm{m}^{2}$ to $31.8 \mathrm{~kg} / \mathrm{m}^{2}$ after 3 months, $30.5 \mathrm{~kg} / \mathrm{m}^{2}$ after 6 , and $29.6 \mathrm{~kg} / \mathrm{m}^{2}$ after $12 \mathrm{months}$, and remained at this level for another 12 months. The average amount of adipose tissue decreased from $40.98 \pm 7.1 \%$ to $38.34 \%$ after 3 months, $36.26 \%$ after 6 , $34.69 \%$ after 12 , and $34.43 \%$ after 24 months.

Conclusions: Due to lifestyle adjustments, about $70 \%$ of the subjects achieved satisfactory results in the weight-loss process. The majority of these individuals were able to maintain satisfactory body mass loss in the longer term. After 24 months of observation, in about $1 / 3$ of the individuals, a tendency to an increase in body weight and adipose tissue was observed, and in some cases a total regain of pre-treatment body mass. In order to improve the effectiveness and stability of the weight-loss process, it is necessary to conduct further studies aimed at identifying the causes for this phenomenon.
\end{abstract}

\section{Streszczenie}

Wprowadzenie: Redukcja masy ciała o 5\% do 10\% wiąże się ze znaczącym zmniejszeniem ryzyka wystąpienia chorób, u podłoża których leży otyłość.

Cel pracy: Analiza zmian masy i składu ciała u pacjentów z nadwagą i otyłością poddanych terapii odchudzającej.

Materiał i metody: Do badania zakwalifikowano 129 osób z nadwagą i otyłością prostą. Pacjenci zostali poinstruowani, aby przestrzegać zdrowej, zbilansowanej diety opracowanej na podstawie norm żywieniowych. Pacjenci zostali poddani także pomiarom antropometrycznym oraz badaniom składu ciała metodą bioimpedancji. W analizie uwzględniono pomiary wykonane po upływie 3, 6, 12 i 24 miesięcy od pierwszej wizyty. Do przetestowania zmian masy i składu ciała w kolejnych miesiącach terapii zastosowano jednoczynnikową analizę wariancji.

Wyniki: Średni wskaźnik masy ciała pacjentów zmniejszył się podczas kolejnych wizyt kontrolnych z $33,8 \pm 5,17 \mathrm{~kg} / \mathrm{m}^{2}$ do $31,8 \mathrm{~kg} / \mathrm{m}^{2}$ po $3,30,5 \mathrm{~kg} / \mathrm{m}^{2}$ po $6,29,6 \mathrm{~kg} / \mathrm{m}^{2}$ po 12 miesiącach i pozostał na tym poziomie przez kolejnych 12 miesięcy. Średnia ilość tkanki tłuszczowej zmniejszyła się z 40,98 $\pm 7.1 \%$ do 38,34\% po 3, do 36,26\% po 6, do 34,69\% po 12 i do 34,43\% po 24 miesiącach.

Wnioski: Dzięki modyfikacji stylu życia ok. 70\% badanych osiągnęło zadowalające rezultaty w procesie odchudzania. Większość tych osób była w stanie utrzymać akceptowalną utratę masy ciała w dłuższym czasie. Po 24 miesiącach obserwacji u ok. 1/3 pacjentów stwierdzono jednak tendencję do ponownego zwiększenia masy ciała i ilości tkanki tłuszczowej, a w niektórych przypadkach doszło nawet do powrotu do masy ciała sprzed terapii. Aby zwiększyć skuteczność i trwałość procesu odchudzania niezbędne jest prowadzenie dalszych badań mających na celu poszukiwanie przyczyn tego zjawiska. 


\section{Introduction}

The number of obese people in the world, despite ongoing prevention and treatment, is rapidly increasing [1]. This is accompanied by an increasing number of patients with obesity complications. It is widely known that a reduction of $5 \%$ to $10 \%$ of body mass is related to a significantly lower risk of the occurrence of conditions whose underlying cause is obesity [2-4]. The majority of patients subjected to weight loss treatment are able to achieve such an effect. It is obvious that the pace of weight loss and the value of the achieved weight loss is an individual issue for each patient and is dependent on such factors as: initial body mass, number and type of poor dietary habits, family occurrence of obesity, coexisting diseases, medication, etc. However, we expect that during treatment patients will achieve the desired results, i.e. weight loss from 0.5 to $1 \mathrm{~kg}$ per week, which corresponds to 2 to $4 \mathrm{~kg}$ per month. Assuming such values, we are able to approximately determine the time a patient needs to obtain normal body mass. It is known that not all patients are able to achieve such results, especially if they start weight loss treatment from the level of super obesity. However, even for those individuals who obtain satisfactory effects, maintaining a normal body mass after the weight loss process is still challenging. A significant number of patients trying to lose weight, sooner or later, experience the yo-yo effect [5]. Several authors indicate that maintaining a reduced body mass after the weight loss phase is a much more serious problem than weight loss itself [6-9].

\section{Aim of the research}

The aim of this study was the examination of body mass and composition changes in overweight and obese patients subjected to weight-loss treatment.

\section{Material and methods}

The study was conducted from 11.2007 to 02.2013 and involved 129 patients (105 women and 24 men) with overweight, and simple obesity (body mass index (BMI) $33.8 \pm 5.17 \mathrm{~kg} / \mathrm{m}^{2}$ ), who came to the clinic in order to treat their overweight or obesity. The project was given approval by the Bioethics Committee of the Faculty of Medicine and Health Sciences of the Jan Kochanowski University in Kielce. The study was based on the analysis of medical documentation. Patients consciously agreed to the use of their data for scientific purposes. The average age of the subjects was 36.6 (from 18 to 69) years. After calculating each participant's individual calorie intake needs, a calorie intake lowered by 600 calories per day was calculated. All patients were instructed to follow a healthy diet, given a balanced diet: total fat content below 30\% and animal fats below $10 \%$ of energy value of a daily calorie intake, protein content of $20-22 \%$, carbohydrate content of more than
$55 \%$, with a reduction of simple sugars and products with a high glycaemic index. The diet composition was calculated using the DIETA 4 program. The diet involved five meals a day, consumed about every $3.5 \mathrm{~h}$. The elimination of sweets from the diet and an increase of liquid intake up to $2.5 \mathrm{l}$ /day (including 1.51 of table water or other non-sweetened beverages) were recommended. During the study, the intake of calories based on the current energy needs of the patients was modified, but the composition of the diet did not change significantly. Those patients who were physically active (fitness classes, cycling, swimming, aquaerobics) were instructed to maintain this activity at the same level at least. The patients who were not active had physical activities selected depending on their level of obesity, earlier experiences, and possible contraindications against some types of exercise. They were encouraged to exercise at least three times a week for about 30-40 min, with the intensity of the training not exceeding 70\% maximal heart rate (HRmax).

The patients underwent anthropometric measurements and body composition tests by means of bioimpedance analysis, with the use of a Bodystat 1500 device. The abovementioned measurements and analyses were performed every 6-8 weeks for the whole treatment period. The analysis included measurements performed $3,6,12$, and 24 months after the first appointment. The patients who resigned from the treatment before a lapse of 6 months from the first appointment were excluded from the study. The pace of the total body mass reduction and changes related to body composition were examined (the amount of adipose tissue, body water content, and fat-free mass).

\section{Statistical analysis}

Statistical analysis involved the calculation of average values and standard deviations, medians, minimum and maximum, the range of 25-75 centiles, and the normality of the distribution of characteristics. One-factor analysis of variance was applied to test the changeability of body mass and body composition in the following months. Levene's test of variance of homogeneity was performed, followed by the StudentNewman-Keuls Test for the comparison of pairs. The significance level was adopted at the level of $p<0.05$.

\section{Results}

The characteristic of the subject group in the first test is presented in Table 1. The average body mass decreased from $94.4 \pm 17.3 \mathrm{~kg}$ to $88.9 \mathrm{~kg}$ after 3 months, which resulted in a loss of $5.5 \mathrm{~kg}$ (on average $1.83 \mathrm{~kg}$ per month) (Figure 1). During subsequent follow-up appointments, a systematic loss of body weight was observed to $85.1 \mathrm{~kg}$ after 6 months $(3.8 \mathrm{~kg}$ loss in 3 subsequent months) and $82.9 \mathrm{~kg}$ after 12 months ( $2.2 \mathrm{~kg}$ loss in 6 subsequent months). Twelve months after the last appointment, which is 24 months after 
Table 1. The characteristics of the study participants - results of first examination

\begin{tabular}{|lcccc|}
\hline Parameter & Mean \pm SD & Median (min.-max.) & $\mathbf{2 5}^{\text {th }}-\mathbf{7 5 ^ { \text { th } }}$ percentiles & Normal distribution \\
Age & $36.6 \pm 12.2$ & $35.0(18.0-69.0)$ & $28.0-45.0$ & 0.072 \\
Height & $166.9 \pm 7.1$ & $166.0(153.0-190.0)$ & $162.0-170.3$ & 0.008 \\
Weight & $94.4 \pm 17.3$ & $91.1(66.0-155.0)$ & $81.2-108.0$ & 0.001 \\
BMI & $33.8 \pm 5.2$ & $33.2(24.3-49.9)$ & $29.4-37.5$ & 0.083 \\
\%BF & $41.0 \pm 7.1$ & $40.7(23.3-59.6)$ & $36.6-45.3$ & 0.480 \\
TBW & $45.4 \pm 3.3$ & $45.2(29.2-52.4)$ & $43.8-47.5$ & $<0.001$ \\
FFM & $32.7 \pm 2.8$ & $32.9(24.5-39.1)$ & $31.2-34.3$ & 0.252 \\
\hline
\end{tabular}

$\% B F-$ percentage of body fat, TBW - total body water, FFM - fat-free body mass.

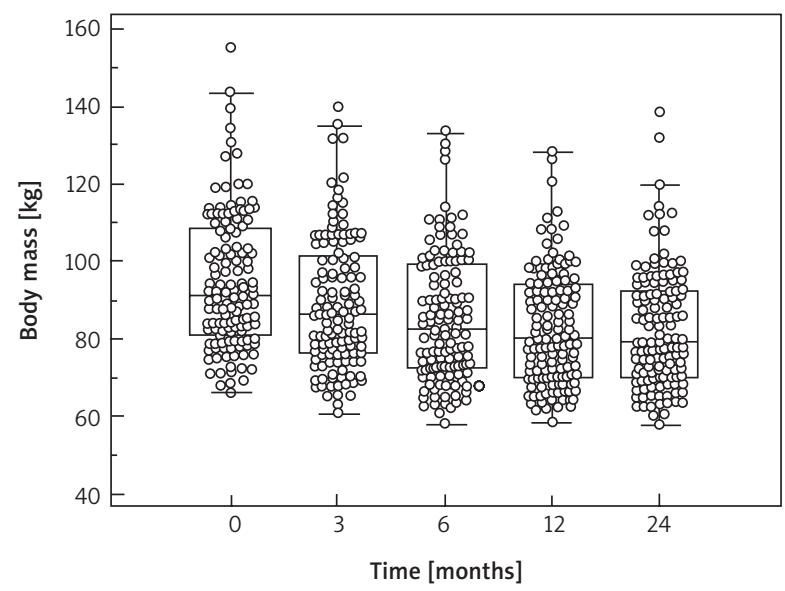

Figure 1. Patient body mass at the beginning and during the weight loss treatment; $(F[4,645]=12.44, p<0.001)$. Statistically significant differences between average scores in the following months of the study, calculated by means of a post hoc test: $0-3,0-6,0-12,0-24,3-12,3-24$

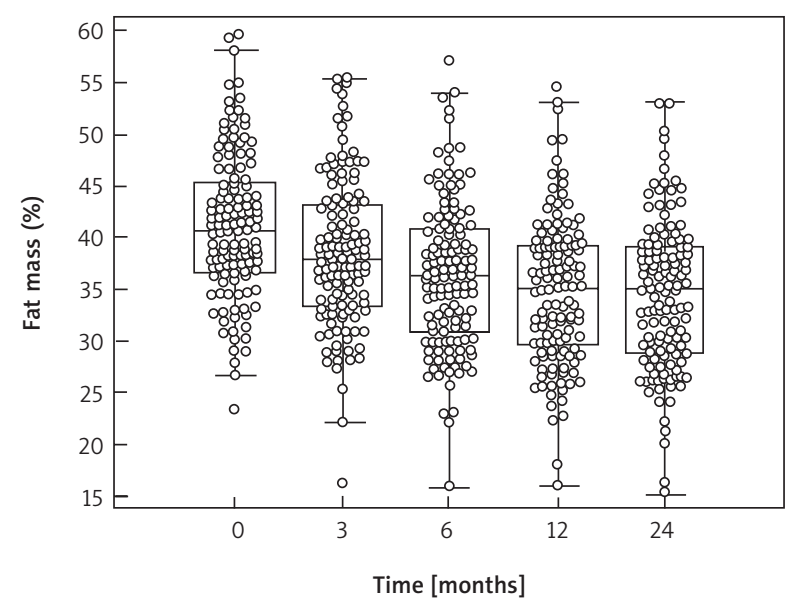

Figure 3. Fat mass of the patients at the beginning and during weight loss treatment; $(F[4,645]=19.16, p<0.001)$. Statistically significant differences between average scores in the following months of the study, calculated by means of a post hoc test: $0-3,0-6,0-12,0-24,3-6,3-12,3-24$

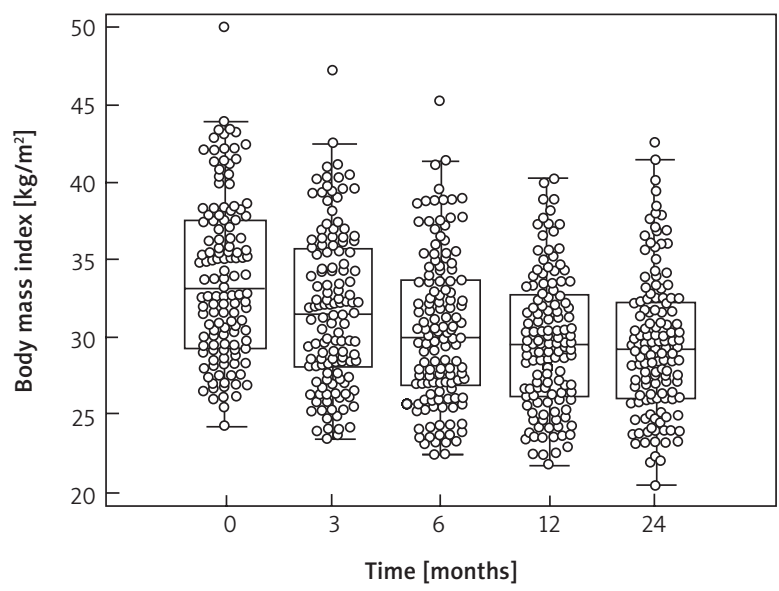

Figure 2. Body mass index at the beginning and during the weight loss treatment; $(\mathrm{F}[4,645]=17.89, p<0.001)$. Statistically significant differences between average scores in the following months of the study, calculated by means of a post hoc test: $0-3,0-6,0-12,0-24,3-6,3-12,3-24$

qualification for the study, the average body weight of the subjects equalled $82.5 \mathrm{~kg}$. The BMI of the patients decreased during subsequent follow-up appointments from $33.8 \pm 5.17 \mathrm{~kg} / \mathrm{m}^{2}$ to $31.8 \mathrm{~kg} / \mathrm{m}^{2}$ after 3 months, $30.5 \mathrm{~kg} / \mathrm{m}^{2}$ after 6 months, $29.6 \mathrm{~kg} / \mathrm{m}^{2}$ after 12 months, and remained at this level for another 12 months (Figure 2). The average amount of adipose tissue decreased from $40.98 \pm 7.1 \%$ to $38.34 \%$ after 3 months, $36.26 \%$ after 6 months, $34.69 \%$ after 12 months, and $34.43 \%$ after 24 months (Figure 3 ). The changes described above were accompanied by an increase in water content in the body (Figure 4) and lean mass (Figure 5).

\section{Discussion}

According to the definition by Wing and Hill, individuals who have intentionally lost at least $10 \%$ of their body weight and kept it off for at least 1 year should be considered to be people who have effectively decreased their body mass [10]. 


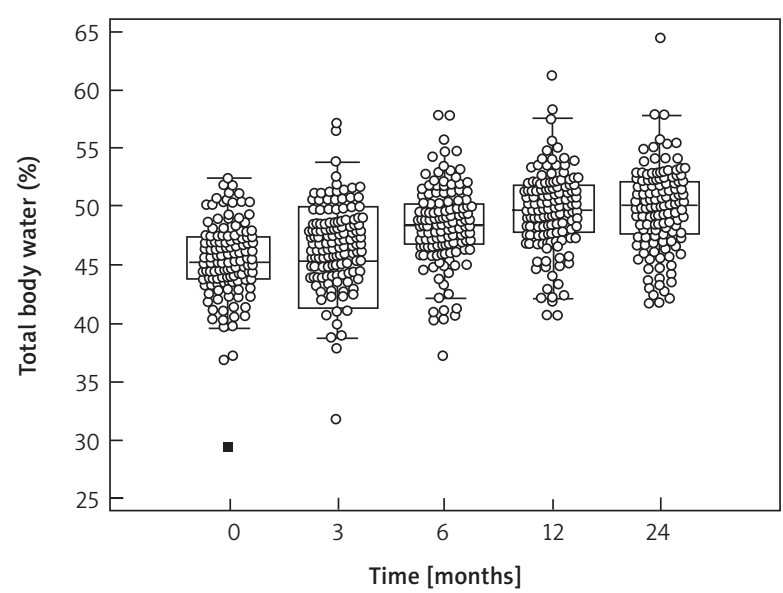

Figure 4. Total body water at the beginning and during the weight loss treatment; $(F[4,643]=38.96, p<0.001)$. Statistically significant differences between average scores in the following months of the study, calculated by means of a post hoc test: $0-3,0-6,0-12,0-24,3-6,3-12,3-24$, $6-12,6-24,12-24$

The results of the conducted study revealed that after 12 and 24 months of observation, body mass reduced by at least $10 \%$ compared to the weight recorded during the first examination. This was present in 92 individuals after 12 months (71.3\%) and 88 individuals after 24 months (68.2\%), respectively. These results should be considered satisfactory in comparison with the results achieved by other authors [11-13]. The meta-analysis of the scores related to following various programs modifying lifestyle has shown that about $30 \%$ of participants had weight loss $\geq 10 \%, 25 \%$ between $5 \%$ and $9.9 \%$, and $40 \% \leq 4.9 \%$ [11]. The lowest effectiveness of losing weight defined as weight loss maintained for at least 1 year was described in the group of 14,306 adult Americans (the 1999-2006 National Health and Nutrition Examination Survey) [12]. The study showed that among the participants who had ever been overweight or obese, only $17.3 \%$ reduced their body weight by the recommended 10\% and kept it off for at least a year. In the weight-loss program presented by Carney et al. [14], in which meal substitutes were used in order to reduce the intake of calories in combination with behavioural therapy, weight loss equalled $16.2 \mathrm{~kg}(14.4 \%)$ for $61 \%$ of the participants who completed a 16-month treatment. Only Thomas et al. [15] concluded that as many as $87 \%$ of participants were still maintaining at least a $10 \%$ weight loss after 5 and 10 years.

In the period between 12 and 24 months from the beginning of the treatment, in 41 of the subjects $(31.8 \%)$, another gain in body mass was observed, and in $36.4 \%$ an increase of adipose tissue was noted. In consequence, after 24 months it was higher than or equal to the weight from the first examination in 6 individuals (4.7\%), while the percentage of the amount

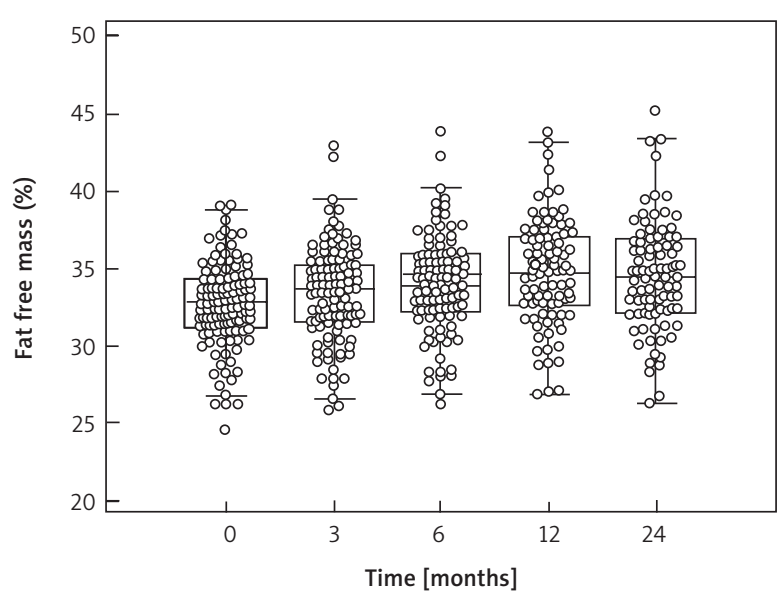

Figure 5. Fat free mass of the patients at the beginning and during the weight loss treatment; $(F[4,506]=7.12$, $p<0.001)$; Statistically significant differences between average scores in the following months of the study, calculated by means of a post hoc test: $0-6,0-12,0-24,3-12,3-24$

of adipose tissue after 24 months from the commencement of the treatment was higher compared with the amount in the first examination in 10 (7.8\%) subjects. Several authors emphasise that maintaining a reduced body mass after the completion of weight loss poses a much greater problem than the weight loss process itself [5-9]. Coughlin et al. [16] showed that after 30 months from the intervention, a continuation of the weight loss program for another 30 months turned out not to have any additional benefits. Carney et al. [14] concluded that among individuals whose weight loss after 16 months of treatment was $16.2 \mathrm{~kg}$ (14.4\%), more than 2 years later the loss was maintained at a level of $14.3 \mathrm{~kg}(12.9 \%)$ compared with the initial body weight.

\section{Conclusions}

The scores of the conducted study show that due to lifestyle changes, about $70 \%$ of the subjects achieved satisfactory results in the weight-loss process and that the majority of those individuals were able to maintain the desired body mass loss in the longer term. These promising findings should stimulate researchers to take further action related to the treatment of obesity, involving lifestyle adjustments. After 24 months of observation, in about $1 / 3$ of the individuals a worrying tendency towards a new increase of body and fat mass was noted, and in some cases total pre-treatment body weight regain occurred. In order to improve the effectiveness and durability of the weight loss process, it is necessary to conduct further studies aimed at finding the reasons for this phenomenon.

\section{Conflict of interest}

The authors declare no conflict of interest. 


\section{References}

1. Ng M, Fleming T, Robinson M, Thomson B, Graetz N, Margono C, Mullany EC, Biryukov S, Abbafati C, Abera SF, Abraham JP, Abu-Rmeileh NM, Achoki T, AlBuhairan FS, Alemu ZA, Alfonso R, Ali MK, Ali R, Guzman NA, AmmarW, Anwari P, Banerjee A, Barquera S, Basu S, Bennett DA, Bhutta Z, Blore J, Cabral N, Nonato IC, Chang JC, Chowdhury R, Courville KJ, Criqui MH, Cundiff DK, Dabhadkar KC, Dandona L, Davis A, Dayama A, Dharmaratne SD, Ding EL, Durrani AM, Esteghamati A, Farzadfar F, Fay DF, Feigin VL, Flaxman A, Forouzanfar MH, Goto A, Green MA, Gupta R, Hafezi-Nejad N, Hankey GJ, Harewood HC, Havmoeller R, Hay S, Hernandez L, Husseini A, Idrisov BT, Ikeda N, Islami F, Jahangir E, Jassal SK, Jee SH, Jeffreys M, Jonas JB, Kabagambe EK, Khalifa SE, Kengne AP, Khader YS, Khang YH, Kim D, Kimokoti RW, Kinge JM, Kokubo Y, Kosen S, Kwan G, Lai T, Leinsalu M, Li Y, Liang X, Liu S, Logroscino G, Lotufo PA, Lu Y, Ma J, Mainoo NK, Mensah GA, Merriman TR, Mokdad AH, Moschandreas J, Naghavi M, Naheed A, Nand D, Narayan KM, Nelson EL, Neuhouser ML, Nisar MI, Ohkubo T, Oti SO, Pedroza A, Prabhakaran D, Roy N, Sampson U, Seo H, Sepanlou SG, Shibuya K, Shiri R, Shiue I, Singh GM, Singh JA, Skirbekk V, Stapelberg NJ, Sturua L, Sykes BL, Tobias M, Tran BX, Trasande L, Toyoshima H, van de Vijver S, Vasankari TJ, Veerman JL, Velasquez-Melendez G, Vlassov VV, Vollset SE, Vos T, Wang C, Wang X, Weiderpass E, Werdecker A, Wright JL, Yang YC, Yatsuya $\mathrm{H}$, Yoon J, Yoon SJ, Zhao Y, Zhou M, Zhu S, Lopez AD, Murray CJ, Gakidou E. Global, regional, and national prevalence of overweight and obesity in children and adults during 1980-2013: a systematic analysis for the Global Burden of Disease Study 2013. Lancet 2014; 384: 766-781.

2. Jensen MD, Ryan DH, Apovian CM, Ard JD, Comuzzie AG, Donato KA, Hu FB, Hubbard VS, Jakicic JM, Kushner RF, Loria CM, Millen BE, Nonas CA, Pi-Sunyer FX, Stevens J, Stevens VJ, Wadden TA, Wolfe BM, Yanovski SZ, Jordan HS, Kendall KA, Lux LJ, Mentor-Marcel R, Morgan LC, Trisolini MG, Wnek J, Anderson JL, Halperin JL, Albert NM, Bozkurt B, Brindis RG, Curtis LH, DeMets D, Hochman JS, Kovacs RJ, Ohman EM, Pressler SJ, Sellke FW, Shen WK, Smith SC Jr, Tomaselli GF; American College of Cardiology/American Heart Association Task Force on Practice Guidelines; Obesity Society. 2013 AHA/ ACC/TOS guideline for the management of overweight and obesity in adults: a report of the American College of Cardiology/American Heart Association Task Force on Practice Guidelines and The Obesity Society. Circulation 2014; 129 (25 Suppl 2): S102-S138.

3. Franz MJ, Boucher JL, Rutten-Ramos S, Van Wormer JJ. Lifestyle weight-loss intervention outcomes in overweight and obese adults with type 2 diabetes: a systematic review and meta-analysis of randomized clinical trials. J Acad Nutr Diet 2015; 115: 1447-1463.

4. Soleymani T, Daniel S, Garvey WT. Weight maintenance: challenges, tools and strategies for primary care physicians. Obes Rev 2016; 17: 81-93.

5. Amigo I, Fernández C. Effects of diets and their role in weight control. Psychol Health Med 2007; 12: 321-327.

6. Barte JC, ter Bogt NC, Bogers RP, Teixeira PJ, Blissmer B, Mori TA, Bemelmans WJ. Maintenance of weight loss after lifestyle interventions for overweight and obesity, a systematic review. Obes Rev 2011; 11: 899-906.
7. Mitchell NS, Catenacci VA, Wyatt HR, Hill JO. Obesity: overview of an epidemic. Psychiatr Clin North Am 2011; 34: 717-732.

8. Ramage S, Farmer A, Apps Eccles K, McCargar L. Healthy strategies for successful weight loss and weight maintenance: a systematic review. Appl Physiol Nutr Metab 2014; 39: 1-20.

9. Peirson L, Fitzpatrick-Lewis D, Ciliska D, Usman Ali M, Raina P, Sherifali D. Strategies for weight maintenance in adult populations treated for overweight and obesity: a systematic review and meta-analysis. CMAJ Open 2015; 3: E47-E54.

10. Wing RR, Hill JO. Successful weight loss maintenance. Annu Rev Nutr 2001; 21: 323-341.

11. Christian JG, Tsai AG, Bessesen DH. Interpreting weight losses from lifestyle modification trials: using categorical data. Int J Obes 2010; 34: 207-209.

12. Kraschnewski JL, Boan J, Esposito J, Sherwood NE, Lehman EB, Kephart DK, Sciamanna CN. Long-term weight loss maintenance in the United States. Int J Obes 2010; 34: 1644-1654.

13. Montesi L, El Ghoch M, Brodosi L, Calugi S, Marchesini G, Dalle Grave R. Long-term weight loss maintenance for obesity: a multidisciplinary approach. Diabetes Metab Syndr Obes 2016; 9: 37-46.

14. Carney D, Schultz S, Lim J, Walters W. Successful medical weight loss in a community setting. J Obes Weight Loss Ther 2015; 5. pii: 248. doi:10.4172/2165-7904.1000248.

15. Thomas JG, Bond DS, Phelan S, Hill JO, Wing RR. Weight-loss maintenance for 10 years in the National Weight Control Registry. Am J Prev Med 2014; 46: 17-23.

16. Coughlin JW, Brantley PJ, Champagne CM, Vollmer WM, Stevens VJ, Funk K, Dalcin AT, Jerome GJ, Myers VH, Tyson C, Batch BC, Charleston J, Loria CM, Bauck A, Hollis JF, Svetkey LP, Appel LJ; Weight Loss Maintenance Collaborative Research Group. The impact of continued intervention on weight: five-year results from the weight loss maintenance trial. Obesity (Silver Spring) 2016; 24 : 1046-1053.

\section{Address for correspondence:}

Prof. JKU Edyta Suliga PhD

Department of Prevention of Alimentary Tract Diseases Jan Kochanowski University

al. IX Wieków Kielc 19, 25-317 Kielce, Poland

Phone: +48 413496974

E-mail: edyta.suliga@ujk.edu.pl 